\title{
Melting Behaviour of Ferronickel Slags
}

\author{
CHRISTOPH SAGADIN ${ }^{1,3}$ STEFAN LUIDOLD, ${ }^{1,4}$ \\ CHRISTOPH WAGNER ${ }^{2}$ and CHRISTINE WENZL ${ }^{2}$
}

\begin{abstract}
1.-CD Laboratory for Extractive Metallurgy of Technological Metals, Montanuniversitaet Leoben/ Nonferrous Metallurgy, Franz-Josef-Straße 18, 8700 Leoben, Austria. 2.-RHI AG-Nonferrous Metals, Wienerbergerstraße 9, 1100 Vienna, Austria.3.-e-mail: christoph.sagadin@unileoben.ac.at. 4.—e-mail: stefan.luidold@unileoben.ac.at
\end{abstract}

The industrial manufacturing of ferronickel in electric furnaces produces large amounts of slag with strong acidic character and high melting points, which seriously stresses the furnace refractory lining. In this study, the melting behavior of synthetically produced ferronickel slags on magnesia as refractory material was determined by means of a hot stage microscope. Therefore, slags comprising the main oxides $\mathrm{SiO}_{2}$ (35-70 wt.\%), $\mathrm{MgO}$ (1545 wt.\%) and $\mathrm{Fe}_{2} \mathrm{O}_{3}$ (5-35 wt.\%) were melted in a graphite crucible and afterwards analyzed by a hot stage microscope. The design of experiments, which was created by the statistic software MODDE ${ }^{\circledR}$, included 20 experiments with varying slag compositions as well as atmospheres. The evaluation of the test results occurred at three different characteristic states of the samples like the softening point according to DIN 51730 and the temperatures at which the area of residual cross-section of the samples amounted to $30 \%$ and $40 \%$, respectively, of the original value depending of their $\mathrm{SiO}_{2} / \mathrm{MgO}$ ratio and iron oxide content. Additionally, the thickness of the zone influenced by the slag was measured and evaluated.

\section{INTRODUCTION}

Ferronickel represents an irreplaceable alloying additive for stainless steels and also plays an important role for other materials like nickel-based and other steel alloys.,2 For the metallurgical production of this ferroalloy, wet laterite with a low nickel content of about $1.5-3 \%$ is used. Such a typical oxidic nickel resource consists of $40 \% \mathrm{SiO}_{2}$, $25 \% \mathrm{MgO}, 1 \% \mathrm{Al}_{2} \mathrm{O}_{3}, 15 \% \mathrm{Fe}, 5 \% \mathrm{O}$ (bounded) and about $11 \%$ chemically combined water. The dominating ferronickel production route for oxidic ores includes a rotary kiln and an electric arc furnace with subsequent raffination. Nickel constitutes a relatively noble metal and so it is possible to separate it from the gangue through a carbothermic reaction. Because of the high water content of lateritic ores, a drying process exhibits an advantage prior reduction. After the pretreatment in rotary kilns, electric arc furnaces are widely applied for smelting. Additionally to the raw ferronickel containing about $20 \mathrm{wt} . \%$ nickel, large amounts of a very acidic slag with a high melting point are also produced. This provides a challenge to the metallurgical plant operators and the refractory producers. After the smelting process, the raw ferronickel has to be refined, e.g., in a converter to generate a saleable product. ${ }^{1-3}$

The chemical and physical properties of slags act as important parameters in metallurgy and strongly influence the process control. Consequently, the slag represents not an unwanted by-product but an additional phase, which takes part in chemical reactions that protects the metal against absorption of tramp elements and collects harmful elements from the metal. Therefore, concentrated attention is paid on slag properties like viscosity, density, chemical activity and miscibility, which influence the process. ${ }^{4,5}$

To get a better understanding of the behavior of liquid slags, two different models, the molecular and the ionic theories, can be used. The molecular theory assumes that the oxides are uncharged molecules but it reaches its limits concerning the electrical resistance of liquid slags. During the melting of the slags, the electric conductibility makes an abrupt rise and so slags must consist of positively and negatively charged ions as the ionic 
theory postulates. The ionic model distinguishes between non-metallic oxides having an acidic character and metallic compounds which can be basic or amphoteric. Compounds like $\mathrm{SiO}_{2}$ build stable crystal systems and also in molten form long-chained silicon oxygen complexes composed of $\mathrm{SiO}_{4}^{4-}$ tetrahedrons. The high binding energy of these covalently bonded atoms causes a very high stability and so they do not break down even in liquid form. The $\mathrm{SiO}_{2}$ molecules absorb $\mathrm{O}^{2-}$ ions representing acceptors in the following acid/base reaction: ${ }^{5,6}$

$$
\mathrm{SiO}_{2}+2 \mathrm{O}^{-2} \rightarrow \mathrm{SiO}_{4}^{4-}
$$

Basic oxides, like $\mathrm{CaO}$ or $\mathrm{MgO}$, build ionic compounds which exhibit in solid state a lattice similar to $\mathrm{NaCl}$. When these crystals fuse, their lattice become destroyed and a dissociated electrolytic melt with a disordered composition is generated. Their basic characteristics results from acting as donators: ${ }^{6}$

$$
\mathrm{CaO} \rightarrow \mathrm{Ca}^{2+}+\mathrm{O}^{2-}
$$

The integration of the alkali- and alkaline earth groups breaks down the three-dimensional Si-O-Si network. The addition of more $\mathrm{MeO}$ causes a shortening of the silicate chains, until they appear only as orthosilicates, $\mathrm{SiO}_{4}^{4-}$. In consideration of the ionic theory, the ferronickel slags consists of two main components, $\mathrm{SiO}_{2}$ and $\mathrm{MgO}{ }^{6}$

$$
2 \mathrm{MgO}+\mathrm{SiO}_{2} \rightarrow 2 \mathrm{Mg}^{2+}+\mathrm{SiO}_{4}^{4-}
$$

The ferronickel slags exhibit melting points of around $1500^{\circ} \mathrm{C}$ and are tapped at temperatures about $50^{\circ} \mathrm{C}$ above the melting point to achieve a good separation between slag and metal. Both oxides $\left(\mathrm{MgO}\right.$ and $\left.\mathrm{SiO}_{2}\right)$ are entirely transferred to

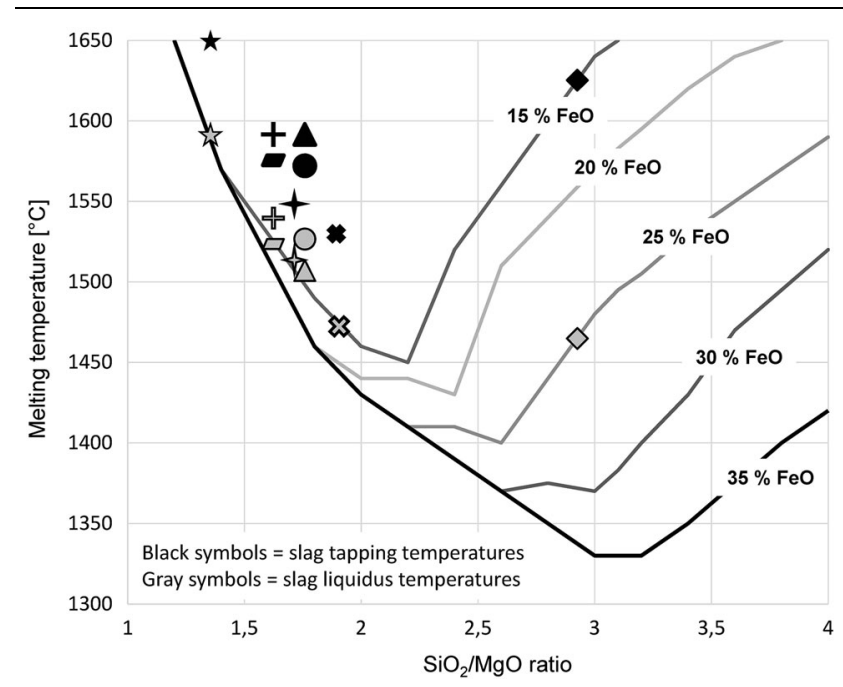

Fig. 1. Melting points of slags as a function of the $\mathrm{SiO}_{2} / \mathrm{MgO}$ ratio with the corresponding tapping temperatures of different producers. ${ }^{7}$

the slag and so the ore has a direct influence on the slag composition. In Fig. 1, the melting temperatures of different industrial slags are shown as a function of their $\mathrm{SiO}_{2} / \mathrm{MgO}$ ratios and $\mathrm{FeO}$ contents. Thus, the slag composition has a direct influence on the melting point and moreover on the required process conditions. ${ }^{7}$

In this study, the melting behavior of different slags in reducing, neutral or oxidising conditions is investigated. Also, the impact of these slags on magnesia refractories was investigated. The results should provide a basis to improve the course of the process flow and optimize the slag metallurgy in the production of ferroalloys.
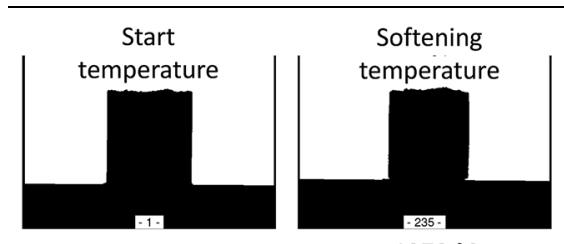

$1378^{\circ} \mathrm{C}$

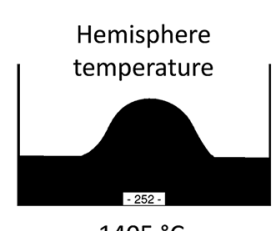

$1405^{\circ} \mathrm{C}$

$30 \%$ area

temperature

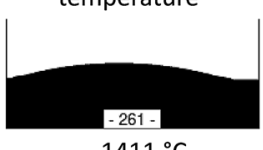

$1411^{\circ} \mathrm{C}$

Fig. 2. Silhouettes of a sample during heating-up in the hot stage microscope.

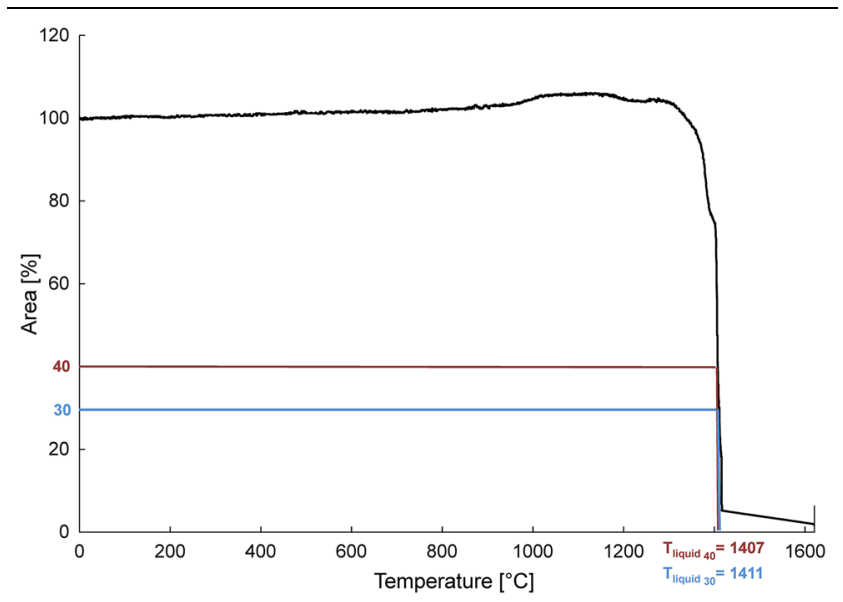

Fig. 3. Cross-section area results of a sample melted in the hot stage microscope. 


\section{MATERIALS AND METHODS}

\section{Method of Analysis by a Hot Stage Microscope (HSM)}

A hot stage microscope was used to analyze the melting behavior of the synthetically produced ferronickel slags. The cylindrical samples were melted by the HSM and software identified characteristic temperatures according to DIN 51730. One of these represents the softening temperature, at which first indications of softening (edge rounding, start of swelling) occur. At a hemisphere temperature, the sample exhibits a shape similar to a hemisphere and its height is half as large as the

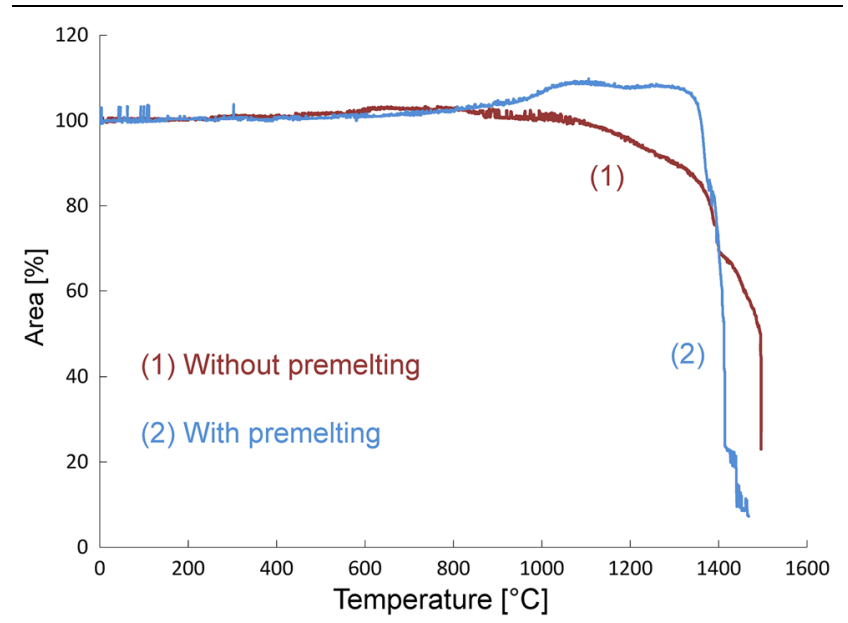

Fig. 4. Comparison of the melting behaviour of a synthetic slag with and without premelting. length of its baseline. Furthermore, the flow temperature is reached when the height of the sample is one-third of its height at hemisphere temperature. However, not all slags yielded results for the flow temperature by this method. So, the evaluation of the measured data was done by the method of Schnideritsch. ${ }^{8}$ Silhouettes at softening, spherical and other characteristic points (see Fig. 2) were compared in order to determine the minimum temperature for complete melting of the sample. Figure 3 shows its cross-sectional area over temperature, including the modified definition of the liquidus temperature at $30 \%$ and $40 \%$, respectively, of the residual cross-section area, because no hemisphere or fluid temperature was identifiable. ${ }^{8}$

\section{Preparation of Synthetic Slag}

In this section, the preparation and characterization of the synthetic slags that only consist of the three main oxides of ferronickel slags, namely $\mathrm{MgO}$, $\mathrm{SiO}_{2}$ and $\mathrm{Fe}_{2} \mathrm{O}_{3}$, is explained. The resultant slag samples served for the subsequent investigation in the HSM. A swing mill, an induction furnace and a hot stage microscope for the investigation of their melting behaviors were used.

\section{Test Procedure}

Before mixing the slag components, quartz was purified with $10 \% \mathrm{HCl}$ followed by annealing. Then, a swing mill served for homogenization of the powder mixture. The following melting process in the induction furnace occurred in a graphite crucible because of its resistance to acidic slags. After reaching the liquidus temperature of the slag, it was

Table I. Design of experiments

\begin{tabular}{|c|c|c|c|c|c|c|c|}
\hline No. of trial & Slag & MgO (wt.\%) & $\mathrm{SiO}_{2}(w \mathrm{t} . \%)$ & $\mathrm{Fe}_{2} \mathrm{O}_{3}($ wt. $\%)$ & Gas & $\mathrm{Fe}^{2+} / \mathrm{Fe}_{\text {tot }}(-)$ & $\mathrm{Fe}^{0} / \mathrm{Fe}_{\text {tot }}(-)$ \\
\hline N1 & $\mathrm{S} 1$ & 45 & 35 & 20 & -1 & 0.38 & 0.61 \\
\hline N2 & S1 & 45 & 35 & 20 & 1 & 0.38 & 0.61 \\
\hline N3 & $\mathrm{S} 2$ & 15 & 70 & 15 & 1 & 0.09 & 0.14 \\
\hline $\mathrm{N} 4$ & S3 & 15 & 50 & 35 & -1 & 0.07 & 0.01 \\
\hline N5 & S3 & 15 & 50 & 35 & 1 & 0.07 & 0.01 \\
\hline N6 & $\mathrm{S} 4$ & 45 & 50 & 5 & -1 & 0.48 & 0.26 \\
\hline N7 & S5 & 25 & 70 & 5 & -1 & 0.12 & 0.08 \\
\hline N8 & S5 & 25 & 70 & 5 & 1 & 0.12 & 0.08 \\
\hline N9 & $\mathrm{S} 2$ & 15 & 70 & 15 & 0 & 0.09 & 0.14 \\
\hline N10 & S6 & 15 & 63 & 22 & -1 & 0.06 & 0.01 \\
\hline N11 & $\mathrm{S} 4$ & 45 & 50 & 5 & 0 & 0.48 & 0.26 \\
\hline N12 & S7 & 30 & 35 & 35 & 0 & 0.87 & 0.09 \\
\hline $\mathrm{N} 13$ & S7 & 30 & 35 & 35 & 0 & 0.87 & 0.09 \\
\hline N14 & S8 & 25 & 40 & 35 & 1 & 0.55 & 0.02 \\
\hline N15 & S9 & 38 & 57 & 5 & 1 & 0.16 & 0.03 \\
\hline N16 & S10 & 29 & 52 & 19 & -1 & 0.17 & 0.03 \\
\hline N17 & S10 & 29 & 52 & 19 & 0 & 0.17 & 0.03 \\
\hline N18 & S10 & 29 & 52 & 19 & 0 & 0.17 & 0.03 \\
\hline N19 & S10 & 29 & 52 & 19 & 0 & 0.17 & 0.03 \\
\hline N20 & S10 & 29 & 52 & 19 & 0 & 0.17 & 0.03 \\
\hline
\end{tabular}


Table II. Experimental results

\begin{tabular}{|c|c|c|c|c|c|c|c|}
\hline $\begin{array}{l}\text { No. of } \\
\text { trial } \\
\end{array}$ & $\begin{array}{c}\text { Softening } \\
\text { temperature } \\
\left({ }^{\circ} \mathrm{C}\right) \\
\end{array}$ & $\begin{array}{c}\text { Sphere } \\
\text { temperature } \\
\left({ }^{\circ} \mathrm{C}\right) \\
\end{array}$ & $\begin{array}{c}\text { Hemisphere } \\
\text { temperature } \\
\left({ }^{\circ} \mathrm{C}\right) \\
\end{array}$ & $\begin{array}{c}\text { Fluid } \\
\text { temperature } \\
\left({ }^{\circ} \mathrm{C}\right) \\
\end{array}$ & $\begin{array}{c}\text { Temperature of } \\
30 \% \text { residual } \\
\text { area }\left({ }^{\circ} \mathrm{C}\right) \\
\end{array}$ & $\begin{array}{c}\text { Temperature } \\
\text { of } 40 \% \text { residual } \\
\text { area }\left({ }^{\circ} \mathrm{C}\right) \\
\end{array}$ & $\begin{array}{c}\text { Area } \\
\left(\mathbf{m m}^{2}\right) \\
\end{array}$ \\
\hline N1 & - & - & - & - & - & - & 0.97 \\
\hline N2 & - & - & - & - & - & - & 1.31 \\
\hline N3 & 1532 & - & 1559 & 1579 & 1571 & 1566 & 8.73 \\
\hline N4 & 1356 & - & 1621 & - & 1427 & 1415 & 5.24 \\
\hline N5 & 1384 & - & 1622 & - & 1448 & 1445 & \\
\hline N6 & 1542 & - & 1562 & 1594 & - & 1621 & 4.79 \\
\hline N7 & 1548 & - & 1583 & 1594 & 1586 & 1578 & 7.06 \\
\hline N8 & 1531 & - & 1574 & 1584 & 1577 & 1573 & 10.27 \\
\hline N9 & 1534 & - & 1620 & - & 1572 & 1567 & 7.35 \\
\hline N10 & 1523 & - & 1593 & - & 1535 & 1530 & 4.23 \\
\hline N11 & 1534 & 1543 & 1550 & - & - & 1622 & 11.65 \\
\hline N12 & 1387 & - & 1434 & 1592 & 1569 & 1508 & 4.21 \\
\hline N13 & 1380 & - & - & - & 1583 & 1523 & \\
\hline N14 & 1375 & 1402 & 1405 & 1408 & 1411 & 1407 & 5.45 \\
\hline N15 & 1525 & 1531 & 1535 & 1538 & 1538 & 1537 & 6.74 \\
\hline N16 & 1447 & - & 1469 & 1481 & 1484 & 1476 & 3.68 \\
\hline N17 & 1411 & - & 1441 & 1471 & 1478 & 1470 & 4.58 \\
\hline N18 & 1370 & 1416 & 1436 & 1476 & 1487 & 1469 & 5.33 \\
\hline N19 & 1399 & - & 1433 & 1463 & 1463 & 1460 & 5.4 \\
\hline $\mathrm{N} 20$ & 1396 & 1421 & 1439 & 1467 & 1467 & 1457 & 5.26 \\
\hline
\end{tabular}

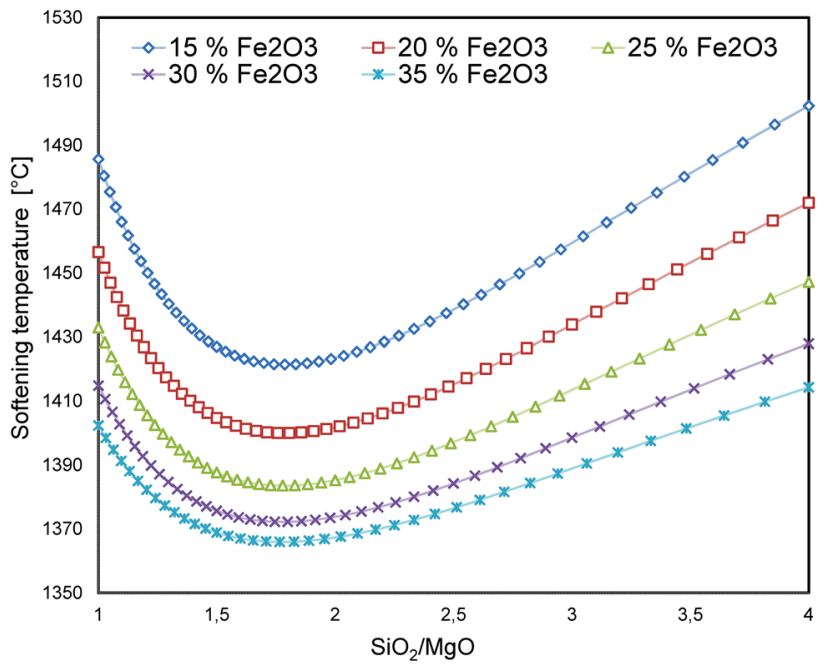

Fig. 5. Dependence of the softening temperature of the $\mathrm{SiO}_{2} / \mathrm{MgO}$ ratio and the $\mathrm{Fe}_{2} \mathrm{O}_{3}$ content in neutral $\mathrm{CO}_{2}$ atmosphere.

quenched on a steel plate at room temperature to achieve high cooling rates. Afterwards, a swing mill ground the solid slag to obtain a fine slag powder.

The focus of this work comprised the analysis of the melting behavior of the slag by the hot stage microscope. For that, a small slag cylinder was pressed and positioned on a $\mathrm{MgO}$ plate. Besides the investigation of the melting behavior of the slags, the corrosion of the magnesia by them, which should simulate the real smelting process, was also determined. For that, a heating of the furnace by $10 \mathrm{~K} / \mathrm{min}$ up to a temperature of $1700^{\circ} \mathrm{C}$ occurred, which corresponds to a sample temperature of about $1620^{\circ} \mathrm{C}$. After that, the temperature remained constant for $1 \mathrm{~h}$ to determine the interaction between the slag and the refractory.

\section{Pre-test to Define Proper Test Conditions}

To find the best experimental conditions closest to the real process, some pre-tests were necessary. One of them comprised the detection of suitable atmospheres. Therefore, a reducing atmosphere with $2 \%$ $\mathrm{H}_{2}$ and $98 \%$ Ar was checked, but its high reduction potential resulted in the generation of pure iron drops out of the Fe oxide contained in the slag. After several tests, it was found that a mixture of $60 \% \mathrm{CO}$ and $40 \% \mathrm{CO}_{2}$ [corresponding to $\mathrm{p}\left(\mathrm{O}_{2}\right)=1.13 \times 10^{-7}$ bar at a temperature of $\left.1620^{\circ} \mathrm{C}\right]$ was the best atmosphere for closest to real processing.

Some tests also investigated the effect of plate material carrying the slag sample. Due to the fact that the magnesia plate did not show a significant influence on the melting behavior of the slag compared to a $\mathrm{Pt} / \mathrm{Rh}$ plate, magnesia served for the following investigations because it allowed the simulation of refractory corrosion.

Additionally, tests with and without premelting of the synthetic slag were performed in the HSM, which illustrated a strong difference in melting behavior (see Fig. 4). For the following experiments, premelted synthetic slag powder was applied to approximate real slags. 


\section{Design of Experiments}

The design of the experiments can be seen in Table I, which includes 20 tests with different slag compositions and varying gas atmosphere in which -1 indicates a gas mixture of $60 \mathrm{vol} . \% \mathrm{CO}$ and 40 vol.\% $\mathrm{CO}_{2}, 1$ synthetic air and 0 pure $\mathrm{CO}_{2}$. Due to the pre-melting of the slag in a graphite crucible,

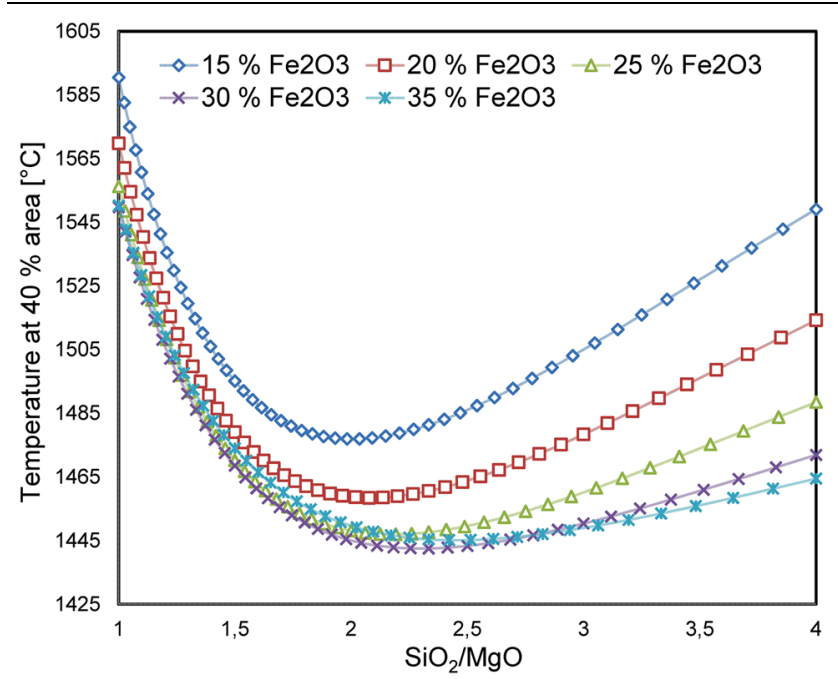

Fig. 6. Dependence of the $40 \%$ residual area of the $\mathrm{SiO}_{2} / \mathrm{MgO}$ ratio and the $\mathrm{Fe}_{2} \mathrm{O}_{3}$ content in neutral $\mathrm{CO}_{2}$ atmosphere. partial reduction of iron oxide took place, the extent of which varied strongly with the slag composition. Therefore, Table I quantifies this effect by the ratios of Fe(II) oxide as well as metallic iron to total iron content. However, the heating of the samples by the HSM in above-mentioned controlled atmospheres compensates these varying oxidation states.

\section{RESULTS AND DISCUSSION}

\section{Experimental Results}

Table II shows the characteristic softening temperatures and temperatures for $30 \%$ and $40 \%$, respectively, residual cross-section area as well as the infiltration area. The tests N1 and N2 achieved no results, because of a too high melting point of slag $\mathrm{S} 1$ of more than $1620^{\circ} \mathrm{C}$, which constitutes the heating limit of the hot stage microscope. Finally, the area of the slag infiltration was manually determined by an optical stereo microscope.

\section{Statistical Evaluation and Interpretation of the Results}

The experimental results were evaluated by the statistic software MODDE ${ }^{\circledR} 11$, which also served for the design of the experiments. The statistical analysis includes the following parameters:

- Softening temperature

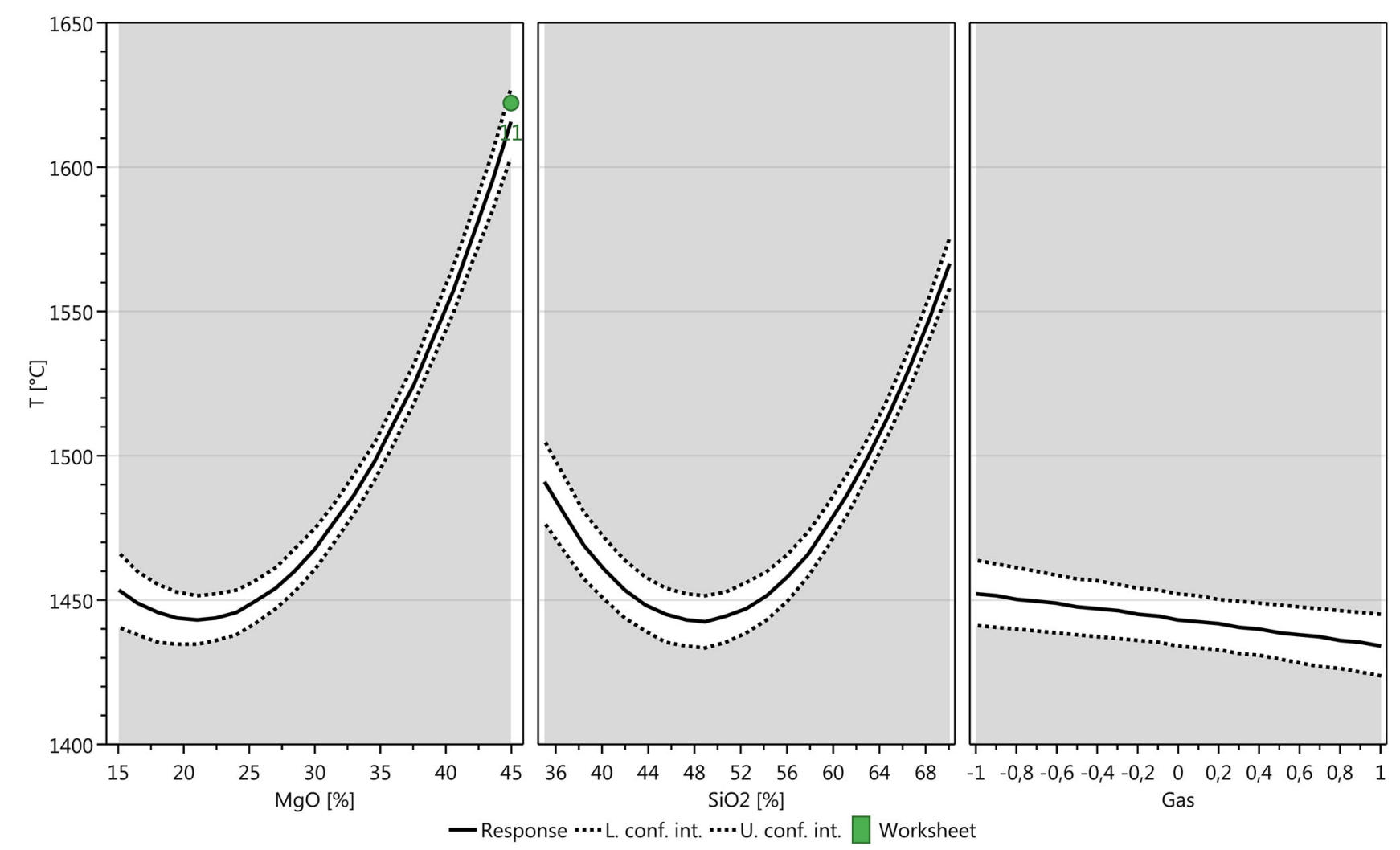

Fig. 7. Representation of the $40 \%$ residual area temperature for $50 \% \mathrm{SiO}_{2}, 20 \% \mathrm{MgO}$ and gas $=0$. 


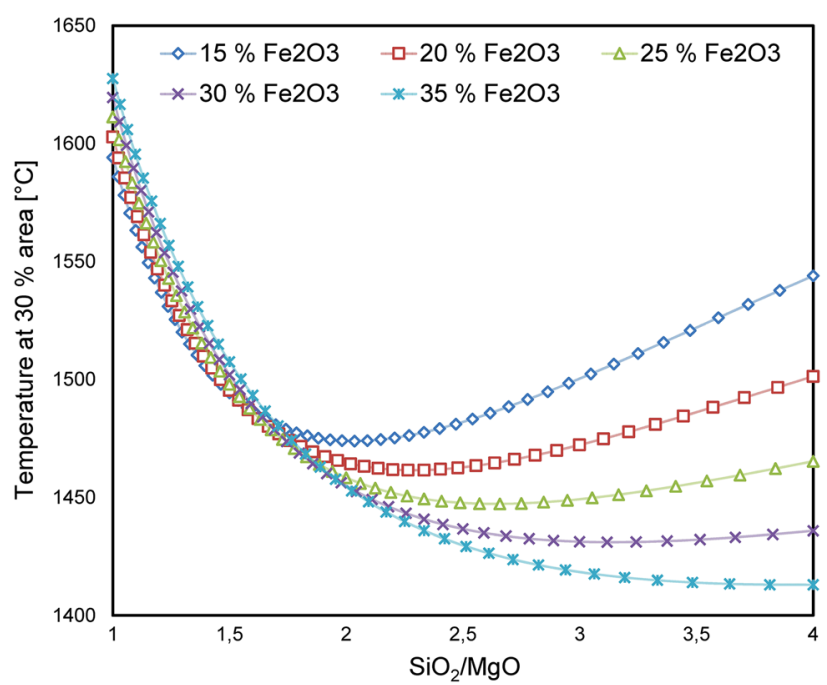

Fig. 8. Dependence of the $30 \%$ residual area of the $\mathrm{SiO}_{2} / \mathrm{MgO}$ ratio and the $\mathrm{Fe}_{2} \mathrm{O}_{3}$ content in neutral $\mathrm{CO}_{2}$ atmosphere.

- Temperature for $40 \%$ residual area

- Temperature for $30 \%$ residual area

- Area of slag infiltration zone

Figure 5 presents the softening temperature dependent on the $\mathrm{Fe}_{2} \mathrm{O}_{3}$ content. An increasing content of iron oxide resulted in a declining softening temperature. At a constant iron oxide concentration, the lowest temperatures appeared in a range of about 1.5-2 for the $\mathrm{SiO}_{2} / \mathrm{MgO}$ ratio.

During heating the furnace, the samples will reach that temperature at which the areas of their silhouettes amount to $40 \%$ of the original area. It is assumed that the liquidus temperature is reached at this point. This temperature (see Fig. 6) exhibits the same trend in dependence on the slag composition as the published data from literature (see Fig. 1), indicating that the lowest temperature is at a $\mathrm{SiO}_{2} / \mathrm{MgO}$-ratio between 2 and 3 .

The next diagrams (see Fig. 7) show the influence of the $\mathrm{MgO}$ and $\mathrm{SiO}_{2}$ content as well as the gas composition on the melting point. The first diagram illustrates the melting temperature in dependence on the $\mathrm{MgO}$ content by a fixed $\mathrm{SiO}_{2}$ content of $50 \%$ and the atmosphere 0 (pure $\mathrm{CO}_{2}$ ), the second in dependence on the $\mathrm{SiO}_{2}$ content by a fixed $\mathrm{MgO}$ concentration of $20 \%$ as well as the atmosphere 0 , and the last one the influence of the atmosphere on the melting temperature at a slag composition of $50 \% \mathrm{SiO}_{2}, 30 \% \mathrm{Fe}_{2} \mathrm{O}_{3}$ and $20 \% \mathrm{SiO}_{2}$. In both cases, an increase of the $\mathrm{MgO}$ and the $\mathrm{SiO}_{2}$ content resulted in higher melting temperatures. The influence of the atmosphere on the melting behavior is very low and in the range of the model inaccuracy.

A similar trend is shown in Fig. 8 at the temperature for a residual cross section area of $30 \%$. The amount of iron oxide in the synthetic slag exhibits a larger impact on the liquidus temperature at higher
$\mathrm{SiO}_{2} / \mathrm{MgO}$ ratios. At low $\mathrm{SiO}_{2} / \mathrm{MgO}$ ratios, the iron oxide content has only a very low influence on the temperature.

\section{Affected Zone of the Refractory by the Slag}

The statistical evaluation of the size of infiltration zones results in a clear rise of the area with increasing $\mathrm{SiO}_{2} / \mathrm{MgO}$ ratios due to the influence of the slag. The area of infiltration appears about three times larger at a ratio of 4 than at a ratio of 1 , whereas the effect of iron oxide content is considerably smaller.

\section{CONCLUSION}

The enormously large slag amounts, their acidic character and high melting temperatures challenge ferronickel and refractory producers. To achieve a better understanding of how the slag acts in the electric furnace, its melting behavior and the corrosion of the refractory caused by the slag was the main topic of this research. Therefore, the analysis by the hot stage microscope proves an excellent method for the determination of its melting behavior. The slags show minimum melting temperatures within the investigated range from 1.5 to 3 for the $\mathrm{SiO}_{2} / \mathrm{MgO}$ ratio. The influence of the iron oxide content, which depends in real processes on the reducing conditions in the furnace, indicates that the melting temperatures fall with rising iron oxide contents. In detail, the comparison of Figs. 5 and 8 indicate that the iron oxide content influences both characteristic temperatures at high $\mathrm{SiO}_{2} / \mathrm{MgO}$ ratios but only the softening temperature at low ones. Several effects cause this diverging behavior, which can be described in detail by thermodynamical calculations (e.g., FactSage). Depending on their composition, diverse solid phases are stable within the melting ranges of these slags, which exhibit differing solubilities for iron(II) oxide and iron(III) oxide. However, the ratio between these both components in the liquid phase also depend on temperature and gas atmosphere. The corrosion of magnesia-based refractory rises with increasing $\mathrm{SiO}_{2} / \mathrm{MgO}$ ratios, whereas the iron oxide has no strong influence on the corrosion.

\section{ACKNOWLEDGEMENTS}

The financial support by the Austrian Federal Ministry of Science, Research and Economy and the National Foundation for Research, Technology and Development is gratefully acknowledged.

\section{REFERENCES}

1. S. Luidold, Refraktärmetalle und Ferrolegierung, script, Montanuniversitaet Leoben, Leoben (2015).

2. F.K. Crudwell, M.S. Moats, V. Ramachandran, T.C. Robinson, and W.G. Davenport, Extractive Metallurgy of Nickel, Cobalt and Platinum-Group Metals (Amsterdam: Elsevier, 2011), pp. 49-93.

3. D.G.E. Kerfoot, in Ullmann's Encyclopedia of Industrial Chemistry, Sixth, Completely Revised Edition, A17, ed. by 
B. Elvers, S. Hawkins and G. Schulz (Weinheim: WileyVCH, 1991), pp. 199-201.

4. H. Antrekowitsch, Metallhüttenkunde 1, script, Montanuniversitaet Leoben, Leoben (2013).

5. J. Schenk, Eisen-und Stahlmetallurgie 1, script, Montanuniversitaet Leoben, Leoben (2012).

6. K. Koch and D. Janke, Schlacken in der Metallurgie (Düsseldorf: Stahleisen, 1984), pp. 5-9.
7. N. Voermann, T. Gerritsen, I. Candy, F. Stober, and A. Matyas, Developments in furnace technology for ferronickel production, in Proceedings of the Tenth International Ferroalloys Congress, South African, Institute of Mining and Metallurgy (2004).

8. H. Schnideritsch, Schmelz - und Reduktionsverhalten von komplexen Sekundärrohstoffen, dissertation, Montanuniversitaet Leoben, Leoben (2010). 